\title{
Pandawan Website Design Based Content Management System As Media E-commerce Transaction
}

\author{
Adrian Sean Bein ${ }^{1}$, Yuliana isma graha ${ }^{2}$,Anggit Panji Pangestu Utomo ${ }^{3}$ \\ Queensland University ${ }^{1}$, University of Raharja ${ }^{2,3}$ \\ 2 George St, Brisbane City QLD $4000^{1}$,JL. Jendral Sudirman No.40 Modern Cikokol \\ Tangerang $15117^{2,3}$ \\ Australia ${ }^{1}$,Indonesia ${ }^{2,3}$ \\ e-mail: $\underline{\text { n10132350@qut.edu.au }}^{1}$, ,iz@raharja.info ${ }^{2}$, anggit.panji@raharja.info $^{3}$
}

To cite this document:

Bein, A., Graha, Y., \& Pangestu, A. (2020). Pandawan Website Design Based Content Management System As Media E-commerce Transaction. Aptisi Transactions On Technopreneurship (ATT), 2(1), 87-97. https://doi.org/https://doi.org/10.34306/att.v2i1.73

\begin{abstract}
As the Regulation of the Minister of Research, Technology and Higher Education of the Republic of Indonesia No. 9 of 2018 concerning the accreditation of scientific journals article 4 which mentions the requirements of scientific journals, it has been announced on the official website page of ARJUNA (National Journal Accreditation), that regarding the Circular of the Director of Intellectual Property Management Number 101 / E5.2 / SE / 2018 dated 18 January 2018 regarding Accreditation of Scientific Periodicals only accepts and processes the proposed national scientific (periodical) journal accreditation that has been managed electronically, so that the assessment process will be easier, faster, accurate and transparent (ARJUNA, 2018). But in reality in the era of the industrial revolution 4.0, the Government was not well organized. There are a total of 3 (three) problems from 2 (two) sides of website users, namely there are still many institutions or agencies that in the management use conventional processes so that people who want to publish their articles digitally are constrained with limited access, there are still minimal agencies that have not been able to provide a forum to provide educational support facilities and Open Journal System (OJS) in the form of attractive website-based e-commerce. In this study there are 2 (two) data collection methods, namely observation and literature study methods. The results of this study are Pandawan e-commerce based websites that provide journal publisher services that can be managed online, as well as solving publisher problems in managing journals online.
\end{abstract}

Keywords: Journal Publisher, Open Journal System (OJS), E-Commerce

\section{Introduction}

In line with the direction of industry technology 4.0 and information that currently has entered the era of globalization, people are not only given a million conveniences unlimited access which is also accompanied by many problems present deep, not least in the world of higher education. Research is wrong an important part in improving the academic atmosphere. At present Indonesia successfully ranked 2nd (second) and rated as an improvement 
international publications for Indonesia. However, the development is still not balanced with even distribution of journal management by digitalization or Open Journal System (OJS) in several institutions or agencies in Indonesia and can lead to gaps for researchers who want to publish scientific papers.

Journal management is also one of the important things in improve the quality of higher education, in a circular KEMENRISTEK Intellectual Property Management Number: 101 / E.5.2 / SE / 2018 Jakarta, 18 January 2018, Subject: Accreditation of Scientific Periodicals Electronics Year 2018 (RISTEK, 2018), section "Proposal Requirements Accreditation of Electronic Scientific Issued Periods "point 1 (one) which reads "Having an electronic version of ISSN (e-ISSN) and / or printing (p-ISSN) if issue in two versions, according to the data in the page http://issn.pdii.lipi.go.id/ "so that from these provisions it can be concluded that electronic ISSN can be obtained by publishing scientific journals through the Open Journal System (OJS). And also explain in PERMENRISTEK No. 9 of 2018 concerning Accreditation Scientific Journal Article 1 paragraph 1 (PERMENRISTEK, 2018) "Scientific Journal is form of reporting or communication that contains scientific work and is published scheduled in electronic form and or printed ". From the existing problems, we need a website-based platform e-commerce Pandawan that provides journal publisher services that can be managed online, and solve the problem of the publisher in managing online journals.

\section{Literature study}

According to Qurotul Aini, the National Journal of Informatics and Network Technology (2018), literature review conducted to identify What methods and gaps exist from previous research where the direction of the The purpose of the research is similar to the field of study.

According to Sara Efrat Efron and Ruth Ravid (2018), literature review A systematic form of testing from research that has been Done before. From analyzing, evaluating, and testing Findings of theories and research of previous experts focused on the research area Related issues. Authors should be able to pour or display Critical, comprehensive, accurate, and convey all the things you need to do In order to advance research being researched.

From 2 (two) research that has been described above, can be concluded That the library study is an activity to seek and study Research that has been conducted in line with the research The authors are doing, then analyzing and evaluating the research So that it can be used as a reference in implementing research That is being done. In this study, the authors used 6 (six) Literature review is as follows:

\begin{tabular}{|l|l|l|l|}
\hline Penulis & Judul & Metodologi & Hasil \\
\hline $\begin{array}{l}\text { 1. Alamsyah } \\
\text { Adi Nugroho }\end{array}$ & $\begin{array}{l}\text { Membangun Aplikasi } \\
\text { E-Commerce Dengan } \\
\text { Sistem Penunjang } \\
\text { Keputusan }\end{array}$ & Content & $\begin{array}{l}\text { Kemampuan } \\
\text { untuk melakukan } \\
\text { transaksi, serta } \\
\text { memunculkan } \\
\text { notifikasi } \\
\text { rekomendasi } \\
\text { produk pada } \\
\text { halaman website } \\
\text { sehingga calon } \\
\text { pelanggan Toko } \\
\text { Islam Malang } \\
\text { dapat dengan } \\
\text { cepat }\end{array}$ \\
\hline
\end{tabular}

Pandawan Website Design Based... 


\begin{tabular}{|c|c|c|c|}
\hline & & & $\begin{array}{l}\text { mendapatkan } \\
\text { informasi terbaru } \\
\text { mengenai } \\
\text { produk-produk } \\
\text { yang ada di } \\
\text { dalam toko } \\
\text { tersebut. }\end{array}$ \\
\hline $\begin{array}{l}\text { 1.Santo } \\
\text { 2.Jeferso } \\
\text { 3. Hutahae } \\
\text { an }\end{array}$ & $\begin{array}{l}\text { Aplikasi Toko Buku } \\
\text { Online Berbasis Mobile } \\
\text { "E-Commerce" }\end{array}$ & $\begin{array}{l}\text { Content } \\
\text { Management } \\
\text { System(CMS) } \\
\text { Wordpress }\end{array}$ & $\begin{array}{l}\text { Menyediakan wadah } \\
\text { bagi para penjual } \\
\text { dalam hal ini yaitu } \\
\text { Toko Buku untuk } \\
\text { memberikan } \\
\text { informasi, promosi, } \\
\text { serta transaksi yang } \\
\text { dapat } \\
\text { mempermudah baik } \\
\text { dari pihak pembeli } \\
\text { maupun dari pihak } \\
\text { penjual. }\end{array}$ \\
\hline $\begin{array}{l}\text { 1. Andi Agus } \\
\text { Salim } \\
\text { 2.Soni Fajar } \\
\text { Surya } \\
\text { Gumilang } \\
\text { 3.Muhammad } \\
\text { Azani } \\
\text { Hasibuan }\end{array}$ & $\begin{array}{l}\text { Pengembangan } \\
\text { Aplikasi E-Commerce } \\
\text { Berbasis Website } \\
\text { Menggunakan Content } \\
\text { Management System } \\
\text { (CMS) Wordpress } \\
\text { Pada Startup } \\
\text { Hardcraft.id". }\end{array}$ & $\begin{array}{l}\text { Content } \\
\text { Management } \\
\text { System(CMS) } \\
\text { Wordpress }\end{array}$ & $\begin{array}{l}\text { Mampu } \\
\text { menjembatani } \\
\text { hubungan antara } \\
\text { peminat EKRAF di } \\
\text { seluruh indonesia } \\
\text { dimanapun dan } \\
\text { kapanpun, serta } \\
\text { dapat membantu } \\
\text { pengrajin lokal di } \\
\text { desa yang } \\
\text { berpotensi untuk } \\
\text { dapat menjual hasil } \\
\text { karyanya ke para } \\
\text { peminat EKRAF } \\
\text { seluruh Indonesia. }\end{array}$ \\
\hline $\begin{array}{l}\text { 1.Waliadi } \\
\text { Gunawan } \\
\text { 2.Ely Nuryani } \\
\text { 3.Median } \\
\text { Prasetya }\end{array}$ & $\begin{array}{l}\text { Perancangan Aplikasi } \\
\text { Android Penjualan } \\
\text { Barang Dan Jasa } \\
\text { Berbasis E-Commerce } \\
\text { Pada Pixels Computer } \\
\text { Cilegon Banten" }\end{array}$ & Aplikasi Android & $\begin{array}{l}\text { Aplikasi Android } \\
\text { E-Commerce } \\
\text { penjualan barang } \\
\text { dan jasa yang } \\
\text { mampu memuat stok } \\
\text { produk, promosi, } \\
\text { perhitungan, sampai } \\
\text { dengan } \\
\text { pembayaran. } \\
\text { Sehingga } \\
\text { diharapkan mampu } \\
\text { dapat memberikan } \\
\text { kemudahan bagi } \\
\text { pelanggan dalam }\end{array}$ \\
\hline
\end{tabular}




\begin{tabular}{|c|c|c|c|}
\hline & & & $\begin{array}{l}\text { melakukan transaksi } \\
\text { pemesanan dan } \\
\text { mendapatkan } \\
\text { informasi tentang } \\
\text { Pixels Computer. }\end{array}$ \\
\hline $\begin{array}{l}\text { 1.Kenneth C. } \\
\text { Laudon } \\
\text { 2.Carol } \\
\text { Guercio } \\
\text { Traver }\end{array}$ & $\begin{array}{l}\text { E-commerce: } \\
\text { Business, Technology, } \\
\text { Society }\end{array}$ & $\begin{array}{l}\text { Bricks-andclicks } \\
\text { business models }\end{array}$ & $\begin{array}{l}\text { Teknologi } \\
\text { e-commerce dapat } \\
\text { digunakan untuk } \\
\text { mengurangi biaya } \\
\text { rantai pasokan, } \\
\text { meningkatkan } \\
\text { efisiensi produksi, } \\
\text { dan mempererat } \\
\text { hubungan dengan } \\
\text { pelanggan }\end{array}$ \\
\hline $\begin{array}{l}\text { 1.Sitaresmi } \\
\text { Wahyu } \\
\text { Handani } \\
\text { 2.M. Suyanto } \\
\text { 3.Amir Fatah } \\
\text { Sofyan }\end{array}$ & $\begin{array}{l}\text { Penerapan Konsep } \\
\text { Gamifikasi Pada } \\
\text { E-learning Untuk } \\
\text { Pembelajaran Animasi } \\
3 \text { Dimensi }\end{array}$ & SDLC & $\begin{array}{l}\text { Aplikasi android } \\
\text { e-commerce untuk } \\
\text { memasarkan produk } \\
\text { ke ruang lingkup } \\
\text { yang lebih luas atau } \\
\text { keseluruh dunia dan } \\
\text { meningkatkan } \\
\text { penjualan produk } \\
\text { dengan media yang } \\
\text { dapat diakses oleh } \\
\text { siapa saja, kapan } \\
\text { saja dan dimana } \\
\text { saja }\end{array}$ \\
\hline
\end{tabular}

\section{Research Methods}

3.1 Observation Methods (observations)

According to Abdul Malik Ali et al in the journal optimization, the observation method is a major requirement in the research methodology, which is useful in the process of systematic data collection and logical analysis of data or information, so that it can Provide a conclusion or diagnosis of problems at the research site in order to achieve a goal in research activities.

According to Untung Rahardja DKK in the journal CSRID (2016), observance or observation method is a method of collecting data in research, which is done by observing directly a research object to learn the components Which is used as research material, with the end goal is to get the answers of all the problems faced.

The author conducts the review and observations directly within six (6) months on what is required in the e-commerce website of the journal Publisher Service. From the results of observations that have been conducted, researchers are able to collect data as a source of information to support the process of designing e-commerce website publisher Journal Service. 


\subsection{Library Study Method}

According to Indri Handayani, Erick Febryanto, and Egi Wijatriana Bachri in SISFOTENIKA Journal (2018), stated that the study of the library is a method used in the collection of information or materials from relevant sources according to the topic and Problems of the research object. Library search is the first step to collecting related information for research by defining studies, models, case studies that support topics and determining research scope for research topics.

From the definition above, it can be concluded that the study of the library is an activity to seek and study the research that has been done in line with the research that the author is doing, then analyse and evaluate Research so that it can be used as a reference in the implementation of research that is being done.

\subsection{Data Analysis Techniques}

The stage of data analysis is a step in collecting information about the system that is being researched using data collection methods to be able to find the advantages and disadvantages of running systems. Then, this stage is also done to look for troubleshooting as well as analyze how the system will be built to solve problems in the previous system.

\section{Results And Achieved}


4.1 Proposed system Design
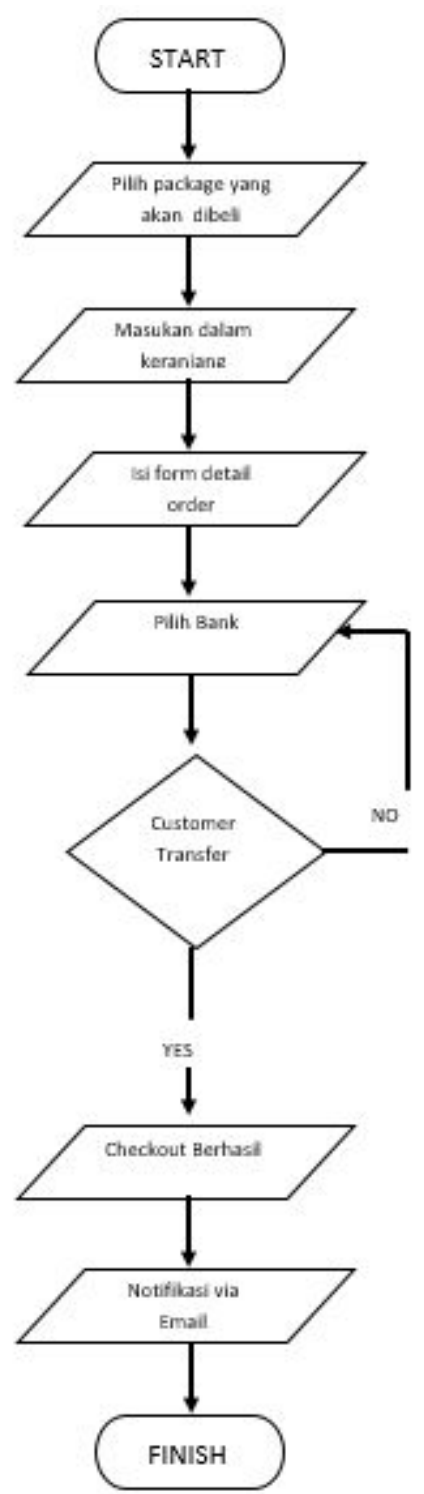

Figure.1 proposed system plot design

Can be explained from the flowchart flow image above proposed using cloud accounting consist of:

1. 2 (two) terminals: that act as "start" and "finish" in the process flow from the beginning of making a booking package journal until it gets notified in the email.

2. 6 (six) Process symbols: Act to demonstrate the process of choosing a package, fill the order form, until checkout.

3. 1 (one) Decision symbol: Act on taking the decision step of the "payment confirmation" if "Yes" then the checkout process succeeds if "No" will show payment via another bank

4.2 Implementation

4.2.1 Main Page view 

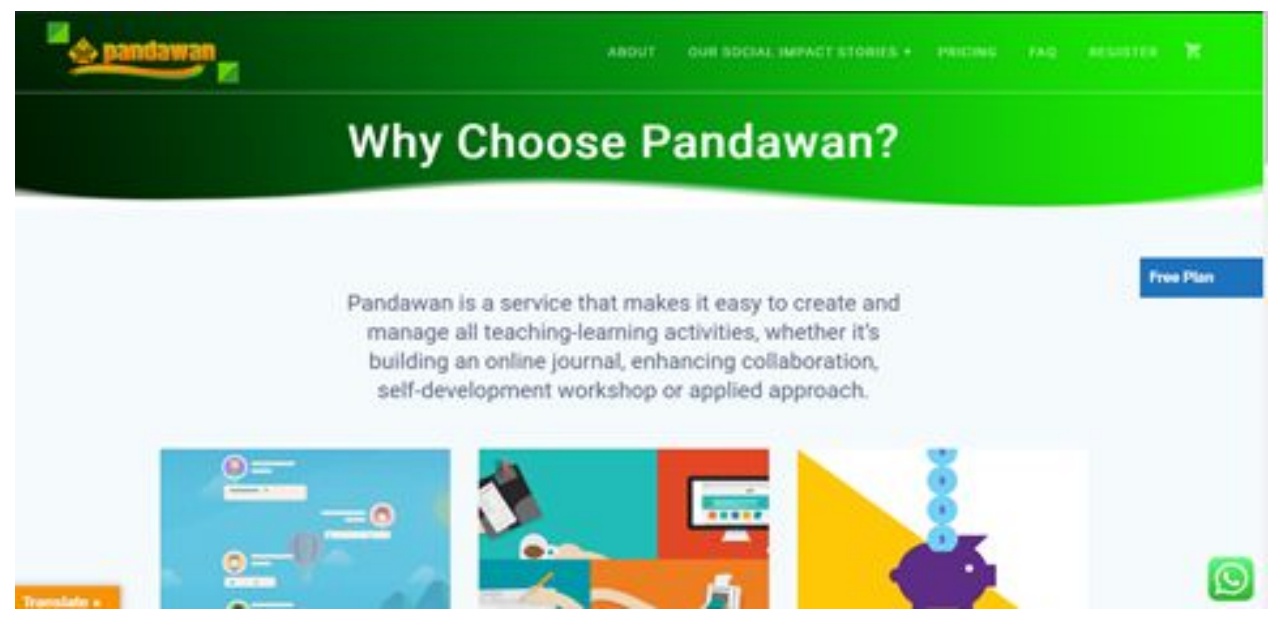

Figure.2 main pageviews

The above image explained that the main Page view can be accessed at https://pandawan.id/and login at https://aptisi.or.id/wp-login.php if it is already registered as a user.

\subsubsection{Page Dashboard View}
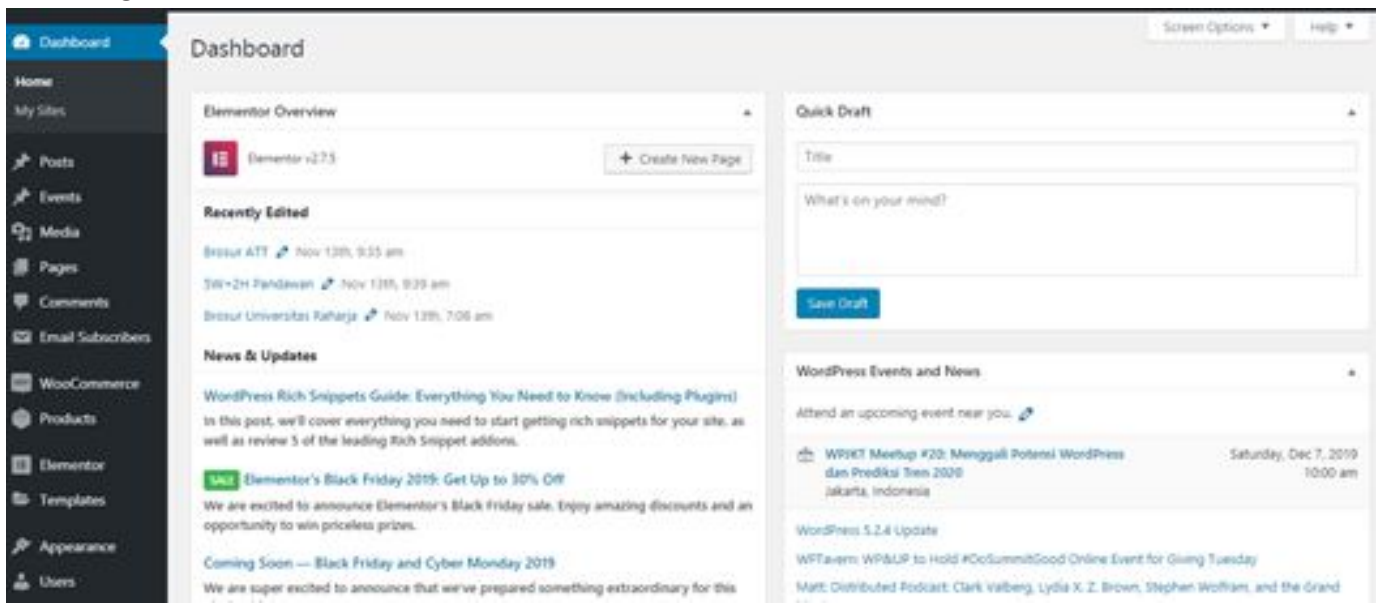

Figure.3 Dashboard view of dashboards

From the above image explained that the dashboard view of the page of Pandawan, inside the dashboard we can get the overall information and create pages and posts. 
4.2.3 Display various packages provided Pandawan

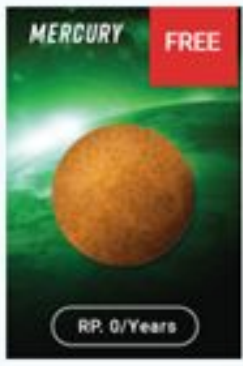

Add to cart

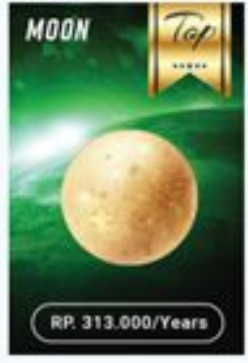

Add to cart

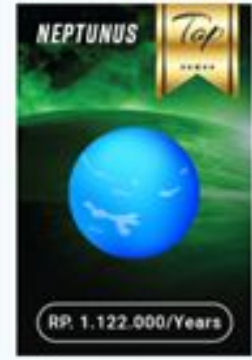

Add to can

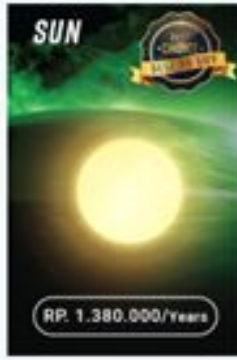

Add to cart

Figure. 3 display various packages provided Pandawan

From the picture above, it is explained that the Pandawan Publisher service has 4 flagship packages, ranging from the free to the various specifications that have their own privileges.

\subsection{4 view of Pandawan Checkout results}

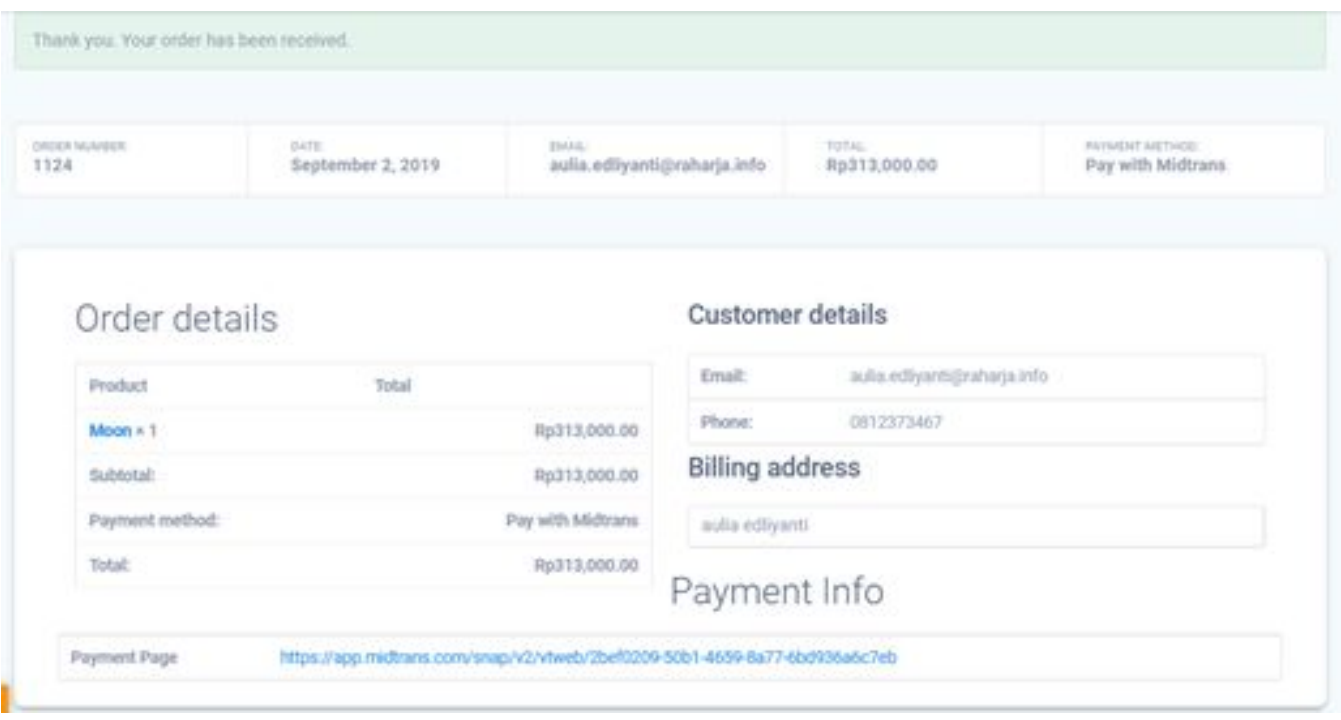

Figure. 4 View of Pandawan Checkout results

From the picture above it is explained that the final process of the transaction in Pandawan will be like the picture above. Where is divided into 2 (two) namely Order Details and Customer Details.

The second stage is the verification stage of the security of documents downloaded and stored by interested parties. This is to ensure information and security [10], [11] because security and privacy are important in guaranteeing and maintaining the author's trust to submit a journal to the Technopreneurship Journal [12], [13], [14], [15] , [16], [17]. The process is as follows:

1. Only the names and emails of the authors listed in the Technopreneurship Journal article can download and store e-LoA

2. The downloader will be asked to verify via email, the verification email is only sent to the emails listed in the article on the Technopreneurship Journal website

3. The system verifies to the blockchain to find out the safety and accuracy of e-LoA recipients 


\section{Conclusion}

Based on the results of research analysis conducted on the e-commerce website to improve the access to the journal and Effectiveness in the management of the journal. Then it can be withdrawn 3 (three) Conclusions:

1. Many agencies or institutions that in the journal Management still use conventional systems, it occurs because of the lack of container publisher of the journal service provider.

2. Implementing an e-commerce website that provides online publisher journal services that can be accessed anytime and anywhere

3. With the existence of a container provider of Publisher-based e-commerce websites will facilitate the customer to conduct transactions online and transparently

\section{References}

[1] Rahardja, U., \& Harahap, E. P. (2019, July). Implementation Of Information Planning And Strategies Industrial Technology 4.0 To Improve Business Intelligence Performance On Official Site Aptisi. In Journal Of Physics: Conference Series (Vol. 1179, No. 1, P. 012111). lop Publishing.

[2] Handayani, I., Aini, Q., \& Sari, N. (2018). Pemanfaatan Sistem ljc Berbasis Ojs Sebagai Media E-journal Pada Stisip Yuppentek. Technomedia Journal, 2(2), 94-106.

[3] Rahardja, U., Handayani, I., \& Wijaya, R. (2018). Penerapan Viewboard Technomedia Journal Menggunakan Sistem llearning Journal Center Pada Perguruan Tinggi. Technomedia Journal, 2(2), 81-93.

[4] Kemenristek Pengelolaan Kekayaan Intelektual. Akreditasi Terbitan Berkala IImiah Elektronik Tahun 2018 (Ristek, 2018). Diakses Pada Tanggal 24 Oktober 2019. Https://Ristekdikti.Go.Id/Wp-content/Uploads/2018/01/Akreditasi-terbitan-berkala-ilmia h-tahun-2018.Pdf.

[5] Permenristek. Akreditasi Akreditasi Jurnal Ilmiah. Diakses Pada Tanggal 24 Oktober 2019.

Https://Risbang.Ristekdikti.Go.Id/Wp-content/Uploads/2019/07/Salinan-permenristekdi kti-nomor-9-tahun-2018.Pdf.

[6] Rahayu, S., Aisyah, E. S. N., \& Farizi, R. (2017). Lapakgue. Co: E-commerce Bagi Pelaku Usaha Mikro Kecil Dan Menengah Pada Komunitas Tangerang Punya Gue. E-proceedings Kns\&I Stikom Bali, 660-665.

[7] Rais, N. S. R., Supriati, R., \& Danti, S. I. (2018). Instalasi Open Journal System (Ojs) Versi 3 Sebagai Pendukung Kegiatan Pengelolaan Dan Publikasi Jurnal Ilmiah. Technomedia Journal, 2(2), 66-80.

[8] Suryana, T. (2017). Open Journal Systems (Ojs). Open Journal Systems (Ojs). 
[9] Merija Jirgensons dan Janis Kapenieks.(2018). Blockchain and the Future of Credential Assessment and Management. Journal of Teacher Education for Sustainability, vol. 20, no. 1, pp. 145-156.

[10] Meitriana, M. A., \& Zukhri, A. (2017). Revitalisasi Jurnal Ilmiah "Ekuitas" Berbasis Open Journal System (Ojs). Proceeding Team, 2, 144-151.

[11] Arimbhi, P., Susanto, I., \& Ghany, S. K. (2019). Proses Bisnis Dan Aspek Pemungutan Pajak Atas Transaksi E-commerce Dalam Era Revolusi Industri 4.0. Jurnal Reformasi Administrasi Jurnal IImiah Untuk Mewujudkan Masyarakat Madani, 6(1), 53-67.

[12] Hariguna, T., Aini, Q., \& Fitriani, R. R. (2020). Penerapan Website E-commerce Sebagai Media Transaksi Pada Perguruan Tinggi. Technomedia Journal, 4(2), 223-234.

[13] Arianti, N. L. N., Darma, G. S., Maradona, A. F., \& Mahyuni, L. P. (2019). Menakar Keraguan Penggunaan Qr Code Dalam Transaksi Bisnis. Jurnal Manajemen Dan Bisnis, 16(2), 67-78.

[14] Zaipin, Z., Suyanto, M., \& Sunyoto, A. (2017). Pengaruh Keamanan, Integritas, Dan Kepercayaan Terhadap Kinerja E-commerce (Studi Kasus Pada Pelanggan E-commerce Kotakom. Com). Jurnal Teknologi Informasi Respati, 7(20).

[15] Maulana, M. (2016). Definisi, Manfaat, Dan Elemen Penting Literasi Digital. Diunduh Tanggal 20 November 2019.

[16] Lawi, M. (2016). Analisis Pengaruh Ukuran Perusahaan, Profitabilitas, Pertumbuhan Penjualan, Dan Tingkat Pajak Terhadap Struktur Modal Bank Umum Syariah Di Indonesia Tahun 2013-2014. Jurnal Pendidikan Akuntansi (Jpak), 4(3).

[17] Widyastuti, T. E. (2016). Pengaruh Sales Promotion Terhadap Pencapaian Tujuan Penjualan Produk Tas Laptop Pada Cv. Niaga Saranatas Bandung (Doctoral Dissertation, Perpustakaan).

[18] Hendini, A. (2016). Pemodelan Uml Sistem Informasi Monitoring Penjualan Dan Stok Barang (Studi Kasus: Distro Zhezha Pontianak). Jurnal Khatulistiwa Informatika, 4(2).

[19] Dewi, I. K., Veza, O., \& Nuraini, N. (2019). Analisis Dan Implementasi Sistem Informasi Penjualan Berbasis Web Pada Ukm Tiara Cakery Batam. Jr: Jurnal Responsive Teknik Informatika, 2(2).

[20] Ilamsyah, I., Katz, R., \& Fitriani, R. R. (2019). The Web-based Internet Cafe (Ric) Raharja Ordering System. Aptisi Transactions On Technopreneurship, 1(1), 93-100.

[21] Aini, Q., Rahardja, U., Moeins, A., \& Wardani, A. M. (2018). Penerapan Data Market Query (Dmq) Pada Sistem Penilaian Berbasis Yii Framework. Infotekjar: Jurnal Nasional Informatika Dan Teknologi Jaringan, 3(1), 26-31.

[22] Efron, S. E., \& Ravid, R. (2018). Writing The Literature Review. Guilford Press.

[23] Nugroho, A. A. (2018). Membangun Aplikasi E-commerce Dengan Sistem Penunjang Keputusan Metode Apriori Untuk Memberikan Rekomendasi Kepada Calon Pembeli Di Toko Islam Malang. J-intech, 6(01), 43-47. 
[24] Santoso, S., \& Hutahaean, J. (2018, September). Aplikasi Toko Buku Online Berbasis Mobile E-commerce. In Seminar Nasional Royal (Senar) (Vol. 1, No. 1, Pp. 339-344).

[25] Salim, A. A., Gumilang, S. F. S., \& Hasibuan, M. A. (2018). Pengembangan Aplikasi E-commerce Berbasis Website Menggunakan Content Management System (Cms) Wordpress Pada Startup Hardcraft. Id. Eproceedings Of Engineering, 5(2).

[26] Gunawan, W., Nuryani, E., \& Prasetya, M. (2018). Perancangan Aplikasi Android Penjualan Barang Dan Jasa Berbasis E-commerce Pada Pixels Computer Cilegon Banten. Jurnal IImiah Sains Dan Teknologi, 2(1), 51-65. 